\title{
Генетический потенциал сибирского генофонда мягкой яровой пшеницы
}

\author{
Шеломенцева Т.В.*, Новохатин В.В. \\ Тюменский научный иентр СО РАН, Тюмень, Россия \\ *e-mail:natalya_sharapov@bk.ru; regina-6087@mail.ru
}

В музее изучалось 67 сортов сибирской селекции: раннеспелых - 20, среднеспелых - 35 и позднеспелых - 12, с выраженной засухоустойчивостью к раннелетней засухе и ограниченной (1.3-1.7) продуктивной кустистостью. У позднеспелых сортов колос длинный и многозерный, что подтверждается сопряженностью между ними и периодом кущения $(r=0.420 \ldots 0.654)$ (при $\mathrm{R} \geq 0.325)$. Урожайность в основном формируется за счет продуктивности колоса $(r=0.663 \ldots 0.756)$. Разнонаправленная сопряженность массы 1000 зерен с озерненностью колоса $(r=-0.164 \ldots+0.426)$ позволяет создавать крупнозерные формы с многозерным колосом. Крупное зерно отличается утонченным перикарпием, что благоприятствует проникновению молекул воды и фитофагов. Оно отрицательно коррелирует с содержанием белка, клейковины, ИДК $(r=-0.395 \ldots-0.598)$. Масса зерна с колоса на одном уровне, значимо коррелирует с его озерненностью $(r=0.616 \ldots 0.787)$ и абсолютной массой зерна $(r=0.679 \ldots 0.715)$, поэтому у новых сортов должно быть оптимальное их соотношение: озерненность колоса 29-31 шт., масса 1000 зерен - 38-41 г. Высокая озерненность ведет к щуплости зерна и снижению абсолютной массы. Предуборочное прорастание зерна в колосе снижает его продуктивность $(r=-0.540)$ и урожайность $(r=-0.602)$. На урожайность отрицательное влияют патогены: бурая ржавчина, септариоз, пыльная головня $(r=-0.334 \ldots-0.441)$. Многозерностью колоса (31-33 шт.) выделяются сорта Тюменская 80, Омская 20, Лютесценс 70, Омская 35, Серебрина, Ильинская, Ария, АВИАДа и раннеспелые сорта Омская 26, Новосибирская 29, СУРЭНТа-6; 34-38 зерен в колосе у Ранга, Чернявы 13, СКЭНТа-3, Икара, Омской 18. Крупная масса 1000 зерен (43-47 г) у Стрелы, Тюменской 80, Чернявы 13, Ильинской, АВИАДы, Веры, Казахстанской 10, Омской 35, Nadine. Мелкозерность (3234 г) отмечена у Тулунской 12 и Новосибирской 15. Устойчивые к прорастанию зерна в колосе у сортов Лютесценс 70, СУРЭНТа-7, Сибирская 14, Лавруша. Высокой белковостью выделяются: Цезиум 111 (17.0-17.2 \%), Хитон (16.0-16.6) и Новосибирская 29 (15.4-17.7 \%). Горизонтальная устойчивость к септариозу и бурой ржавчине у сортов Гренада и Лютесценс 368 . Выделенные сорта рекомендуются для включения в селекционные программы. 